\title{
Determination of Radiation Attenuation Coefficients of Concretes in Different Densities
}

\author{
İ. AkKurt ${ }^{a}, \mathrm{~K}$. GÜnOĞLU ${ }^{a}, \mathrm{C}$. BaşYiĞIT ${ }^{b}$ And A. AKKaŞ ${ }^{c}$ \\ ${ }^{a}$ Suleyman Demirel University, Fen-Edebiyat Fakultesi Fizik Bol., Isparta, Turkey \\ ${ }^{b}$ Suleyman Demirel University, Teknik Egt. Fak. Yapı Egt. Bol., Isparta, Turkey \\ ${ }^{c}$ Suleyman Demirel University, Teknoloji Fak İmalat Müh., Isparta, Turkey
}

\begin{abstract}
The density of the concrete is important parameter for different properties. Using different types and rates of aggregates cause different densities of the concretes. Radiation shielding properties can be varied with the density and it is important to obtain optimum density for this purpose. In this study radiation attenuation coefficients were measured by comparison of five different densities of concrete that called lightweight, semi-lightweight, ordinary and semi-heavyweight and heavyweight. For this purpose concretes were produced with suitable aggregate in laboratory conditions and determined some physical and mechanical properties. The total linear attenuation coefficient measurements have been obtained by a collimated beam of gamma ray from sources ${ }^{60} \mathrm{Co}$.
\end{abstract}

DOI: 10.12693 /APhysPolA.123.374

PACS: $29.30 . \mathrm{Kv}, 34.50 . \mathrm{Bw}$

\section{Introduction}

Concrete is by far the most widely used material for reactor shielding due to its cheapness and satisfactory mechanical properties. It is usually a mixture of hydrogen and other light nuclei and nuclei of fairly high atomic number [1]. The aggregate component of concrete that contains a mixture of many heavy elements play an important role in improving concrete shielding properties and therefore has good shielding properties for the attenuation of photons and neutrons $[2,3]$.

Pumice is a natural material of volcanic origin produced by the release of gases during the solidification of lava. The cellular structure of pumice is created by the molten lava flowing from volcanoes becoming trapped on cooling. The cells are elongated and parallel and sometimes interconnected. Pumice has been used as aggregate in the production of lightweight concrete in many countries of the world $[4,5]$. Turkey has rich reserves of pumice [6].

\section{Experimental details}

In the investigation five different densities of concretes were produced in laboratory conditions; some physical, mechanical and radiation attenuation properties were determined. Samples of concrete in the investigation were prepared using method of absolute volume as a mix design. All types of concretes were produced by using suitable aggregates. Concretes were produced with coarse and fine both pumice aggregates that are called "light weight" coarse pumice, and normal sand aggregates called "semi lightweight" coarse, and fine both normal aggregates called "normal concrete", with both coarse and fine siderite aggregates called "semi heavyweight", and both coarse and fine barite aggregates that called "heavyweight" concretes and they are tagged as LC, SLC, OC, SHC, and HC, respectively.
Portland Cement (PC) 42.5 type of cement from Goltas plant in Isparta was used as binder materials. Pumice aggregate for LC and SLC concretes was obtained from Gölcük region in Isparta. Normal fine aggregates were obtained in Atabey region in Isparta. The nominal maximum aggregate size was kept constant at $16 \mathrm{~mm}$ in all mixtures. Fine and coarse aggregates were separated into two size fractions, $0-4 \mathrm{~mm}$ and $8-16 \mathrm{~mm}$, respectively. Table I shows densities and compressive strengths of concretes. City network water was used as mixing water.

\section{TABLE I}

Densities and compressive strengths of concretes.

\begin{tabular}{c|c|c}
\hline \hline Concrete & $\begin{array}{c}\text { Density } \\
{\left[\mathrm{kg} / \mathrm{m}^{-3}\right]}\end{array}$ & $\begin{array}{c}\text { Comprehensive } \\
\text { strength } \\
{[\mathrm{MPa}]}\end{array}$ \\
\hline LC & 1484 & 14.04 \\
SLC & 1869 & 20.01 \\
OC & 2460 & 24.6 \\
SHC & 2953 & 28.25 \\
HC & 3463 & 35.25
\end{tabular}

The linear attenuation coefficients of concretes have been measured using the gamma spectrometer system containing $\mathrm{NaI}(\mathrm{Tl})$ detector coupled to a digital spectrum analyzer (DSPEC LF) which was a full featured 16k multichannel analyzer on advanced digital signal processing techniques, and were recorded on the MAESTRO-32 gamma spectroscopy software. The measurements have been performed at 1173 and $1332 \mathrm{keV}$ which was obtained from ${ }^{60} \mathrm{Co}$ radioactive sources. The schematic arrangement of the experimental setup used in the present study is shown in Fig. 1.

The photon attenuation coefficients have been evaluated comparing $N$ and $N_{0}$, which are the measured count 


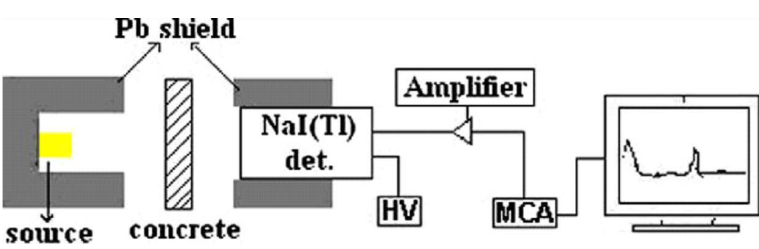

Fig. 1. Schematic view of the experimental setup.

rates in detector, respectively, with and without the absorber of thickness $x(\mathrm{~cm})$

$$
N=N_{0} \mathrm{e}^{-\mu x} \text {. }
$$

\section{Results and discussion}

The linear attenuation coefficients $(\mu)$ for concretes have been measured at the photon energies of 1173 and $1332 \mathrm{keV}$. The obtained results are displayed in Table II. Also, in Fig. 2 it can be seen that the measured results decrease with both increasing photon energy.

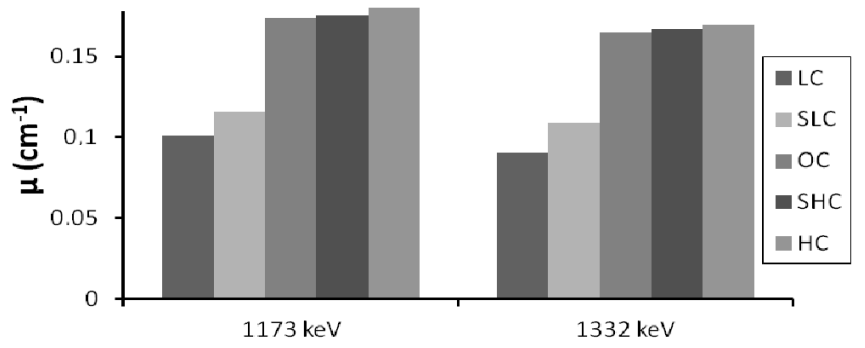

Fig. 2. Measured linear attenuation coefficients.

TABLE II

Measured linear attenuation coefficients.

\begin{tabular}{c|c|c|c|c}
\hline \hline Concrete & $\begin{array}{c}\text { Density } \\
{\left[\mathrm{g} \mathrm{cm}^{-3}\right]}\end{array}$ & $1173 \mathrm{keV}$ & $1332 \mathrm{keV}$ & References \\
\hline LC & 1.484 & 0.101 & 0.090 & present work \\
SLC & 1.869 & 0.115 & 0.109 & present work \\
OC & 2.460 & 0.174 & 0.165 & Akkurt et al. [7] \\
SHC & 2.953 & 0.175 & 0.167 & Akkurt et al. [8] \\
HC & 3.463 & 0.180 & 0.170 & Akkurt et al. [7]
\end{tabular}

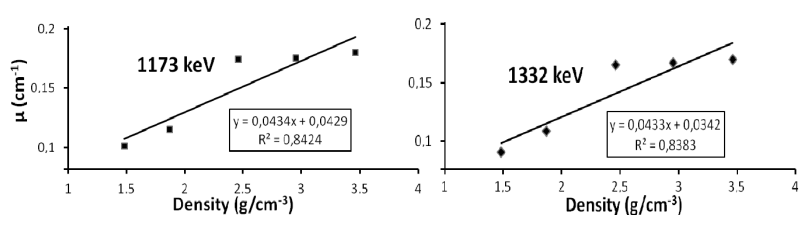

Fig. 3. Variation of the linear attenuation coefficients for the density of concretes.

As the linear attenuation coefficients depend on the material density, it is interesting to plot obtained linear attenuation coefficients as a function of materials density. This has been obtained and displayed in Fig. 3. It is clearly seen from this figure that the linear attenuation coefficients increased with the increasing density of the concretes.

\section{References}

[1] F.A. Ikraiam, A. Abd El-Latif, A. Abd-ELazziz, J.M. Ali, Arab J. Nucl. Sci. Appl. 42, 287 (2009).

[2] A.A. El-Sayed, Ann. Nucl. Energy 29, (1977-1988).

[3] İ. Akkurt, C. Başyiğit, A. Akkaş, Ş. Kılınçarslan, B. Mavi, K. Günoğlu, Acta Phys. Pol. A 121, 138 (2012).

[4] H.M.A. Khandaker, Cement Concrete Res. 34, 283 (2004)

[5] A.M. Nevile, Properties of Concrete, 4th ed., Longman, Harlow, England 1995.

[6] A., Yeğinobalı, G.K. Sobolev, V.S. Soboleva, M. Tokyay, in: 6th CANMET-ACI International Conference on Fly ash, Silica Fume, Slag and Natural Pozzolans in Concrete, Bangkok, Thailand 1998.

[7] I. Akkurt, H. Akyıldırım, B. Mavi, S. Kilincarslan, C. Basyigit, Ann. Nucl. Energy 37, 910 (2010)

[8] C. Basyigit, V. Uysal, S. Kilincarslan, B. Mavi, K. Gunoğlu, I. Akkurt, A. Akkaş, AIP Conf. Proc. 1400, 232 (2012). 